\begin{tabular}{|c|c|}
\hline \multirow{3}{*}{ 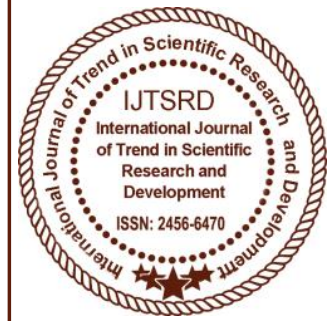 } & $\begin{array}{l}\text { International Journal of Trend in Scientific } \\
\text { Research and Development (IJTSRD) }\end{array}$ \\
\hline & UGC Approved International Open Access Journal \\
\hline & ISSN No: 2456 - 6470 | www.ijtsrd.com | Volume - 1 | Issue - 5 \\
\hline
\end{tabular}

\title{
To Compare the Efficacy of Deep Transverse Friction Massage and Ultrasound in Patients with Upper Trapezius Trigger Points
}

\author{
Jaspinder Kaur* \\ Assistant Professor, DAV Institute of Physiotherapy \\ and Rehabilitation, Jalandhar, Punjab
}

\author{
Tanu Kapila \\ Assistant Professor, DAV Institute of Physiotherapy \\ and Rehabilitation, Jalandhar, Punjab
}

\section{ABSTRACT}

\section{Background and Objective:}

Myofacial trigger point is a common problem worldwide. Myofacial trigger points of upper trapezius muscle leads to neck pain and decreased cervical range of motion that profoundly influence all aspects of daily life.

The purpose of the study was to compare the efficacy of deep transverse friction massage (DTFM) and ultrasound in relieving pain, improving cervical ROM (lateral flexion both sides) and ADL's in patients suffering with upper trapezius trigger points.

\section{Materials and Methods:}

The study was performed among 20 patients of both genders, aged 18-50 years. Subjects were selected on the basis of inclusion criteria and randomly divided into two groups by convenience sampling and allocating alternate patient group A and group B, 10 in each group. Group A was treated with DTFM (5 minutes), Group B was treated with ultrasound (5 minutes), and both the groups along with treatment receive moist pack (15 minutes), passive trapezius stretching, TENS (15 minutes) and cervical isometric exercise (home protocol). Baseline assessments were taken on the $1^{\text {st }}$ day and reassessment was done on $5^{\text {th }}$ and $10^{\text {th }}$ day of treatment session using NPRS, NDI and cervical ROM and data was analyzed.

\section{Results:}

Both the groups showed significant differences in all variables. DTFM and ultrasound both were effective in resolving pain and improving cervical ROM which further lead to improvement in ADL's. But on comparing the mean of both the groups: Group A showed better results than Group B.

\section{Conclusion:}

This study concluded that DTFM and ultrasound both are effective in treatment of myofacial trigger points of upper trapezius muscle but clinically DTFM shows better results.

Keywords: Myofacial trigger points, DTFM, ultrasound

\section{Introduction}

Trigger points are discrete, focal, hyperirritable spots located in a taut band of skeletal muscle. ${ }^{1}$ Patients having trigger points report regional, persistent pain that results in decreased ROM. The muscles used to maintain body posture are affected ${ }^{2}$. The trapezius is broad, flat, superficial muscle of the posterior aspect of the neck and trunk. ${ }^{3}$ Upper fibers of trapezius act with levator scapulae and elevate the scapula. ${ }^{4}$

Researchers believe that the sedentary lifestyle has enhanced the pain. ${ }^{5}$ Motionless body postures and tiresome movements of the shoulder, arm, hand lead to development of musculoskeletal disorders. ${ }^{6,7}$ Occupational/recreational activities that produce repetitive stress on specific muscle/muscle group commonly cause chronic stress in muscle fibers, leading to trigger points. ${ }^{8}$ 
Richard L. Gajdosik reported that clinicians should adopt standardized methods of testing, and goniometric results as ROM measurements. ${ }^{9}$ M. J. H. McCarthy evaluated the NDI by comparison with the Short Form 36 Health Survey Questionnaire. ${ }^{10}$ C.H.Z Hong determined the immediate effectiveness of physical medicine modalities, superficial heat, ultrasound, deep pressure soft tissue massage. ${ }^{11}$

Massage has been considered as treatment of choice for numerous conditions. ${ }^{12,13}$ Applying massage for 5minutes after strenuous exercise is beneficial. $^{14}$ Indirect evidence exists signifying that massage may be beneficial on factors related to an individual's psychological state. These investigations verified improvements in mood status ${ }^{15,16}$ and perception of recovery. ${ }^{17}$

The comparison of two manual treatments for myofascial trigger points in upper trapezius muscle (Ischemic Compression and DTFM). ${ }^{18}$ The statically significant improvement in both decreased visual analogue scale readings and increase in pain pressure thresholds of trigger points tenderness. The results were similar and found that two techniques equally effective in reducing trigger points tenderness. ${ }^{18}$

\section{Methodology}

In study, subjects were selected on the basis of inclusion criteria- age 18-50 (males/females) with upper trapezius trigger points and neck stiffness.
Subjects were excluded with exclusion criteriaInflammatory changes, neurological disorders, pregnant women, infections and tumors. Written consent was obtained after explaining the procedure to the patients.

Sampling method was convenience sampling. Sample design was two groups namely, group A and group B (10 in each group). Group $\mathrm{A}$ was treated with $\operatorname{DTFM}(5$ minutes $)$, Group B was treated with ultrasound (5 minutes). Both the groups receive moist pack (15 minutes), passive trapezius stretching, TENS (15 minutes) and cervical isometric exercise (home protocol). Total 10 sessions of treatment were given within period of 2 weeks.

Baseline assessments were taken on the first day. Exercises were demonstrated and home protocol was explained to the patients. Patients had followed protocol for 10 days. Reassessments were taken on the $5^{\text {th }}$ day and $10^{\text {th }}$ day.

\section{Statistical analysis}

Unpaired t-test was used to compare the scores of baseline assessments between the two groups to find out whether the two groups were comparable or not. The groups have $\mathrm{p}>0.05$ are comparable. Repeated ANNOVA was used to determine the significance of difference within group analysis.

\section{Interpretation}

Table 1: Comparison of scores of (a) NPRS in Group A (b) NDI in Group A (c) Lateral Flexion of neck (Right) in Group A (d) Lateral flexion of neck (Left) in Group A

\begin{tabular}{|c|c|c|c|c|c|c|c|}
\hline \multicolumn{4}{|c|}{ (a) } & \multicolumn{4}{|c|}{ (b) } \\
\hline NPRS & Mean \pm SD & F-test & $P$ value & NDI & Mean \pm SD & F-test & P value \\
\hline Day 1 & $6.50 \pm 0.707$ & & & Day 1 & $50.60 \pm 9.276$ & & \\
\hline Day 5 & $3.50 \pm 1.354$ & 162.74 & $3.555(\mathrm{~S})$ & Day 5 & $29.30 \pm 6.147$ & 205.77 & $3.555(\mathrm{~S})$ \\
\hline Day 10 & $1.40 \pm 0.699$ & & & Day 10 & $14.10 \pm 0.699$ & & \\
\hline \multicolumn{4}{|c|}{ (c) } & \multicolumn{4}{|c|}{ (d) } \\
\hline $\begin{array}{c}\text { Lateral } \\
\text { Bending of } \\
\text { Neck (Right) }\end{array}$ & Mean \pm SD & F-test & $P$ value & $\begin{array}{c}\text { Lateral } \\
\text { Bending } \\
\text { of Neck } \\
\text { (Left) }\end{array}$ & Mean \pm SD & F-test & $P$ value \\
\hline Day 1 & $20.10 \pm 4.149$ & & & Day 1 & $26.10 \pm 4.748$ & & \\
\hline Day 5 & $23.70 \pm 4.423$ & 512.36 & $3.555(\mathrm{~S})$ & Day 5 & $29.00 \pm 5.142$ & 150.76 & $3.555(\mathrm{~S})$ \\
\hline Day 10 & $31.20 \pm 4.492$ & & & Day 10 & $33.50 \pm 5.359$ & & \\
\hline
\end{tabular}


International Journal of Trend in Scientific Research and Development (IJTSRD) ISSN: 2456-6470

Table 2: Comparison of scores of (a) NPRS in Group B (b) NDI in Group B (c) Lateral Flexion of neck (Right) in Group B (d) Lateral flexion of neck (Left) in Group B

\begin{tabular}{|c|c|c|c|c|c|c|c|}
\hline \multicolumn{4}{|c|}{ (a) } & \multicolumn{4}{|c|}{ (b) } \\
\hline NPRS & Mean \pm SD & F-test & $\begin{array}{c}\mathbf{P} \\
\text { value }\end{array}$ & NDI & Mean \pm SD & F-test & $P$ value \\
\hline Day 1 & $6.50 \pm 0.850$ & & & Day 1 & $50.30 \pm 12.202$ & & \\
\hline Day 5 & $4.10 \pm 0.994$ & 297.82 & $\begin{array}{c}3.555 \\
(\mathrm{~S})\end{array}$ & Day 5 & $35.00 \pm 10.541$ & 113.21 & $3.555(\mathrm{~S})$ \\
\hline Day 10 & $2.10 \pm 0.738$ & & & Day 10 & $19.70 \pm 8.616$ & & \\
\hline \multicolumn{4}{|c|}{ (c) } & \multicolumn{4}{|c|}{ (d) } \\
\hline $\begin{array}{c}\text { Lateral } \\
\text { Bending of } \\
\text { Neck } \\
\text { (Right) }\end{array}$ & Mean \pm SD & F-test & $\begin{array}{c}P \\
\text { value }\end{array}$ & $\begin{array}{c}\text { Lateral } \\
\text { Bending } \\
\text { of Neck } \\
\text { (Left) }\end{array}$ & Mean \pm SD & F-test & $P$ value \\
\hline Day 1 & $19.20 \pm 4.29$ & & & Day 1 & $22.40 \pm 5.892$ & & \\
\hline Day 5 & $21.80 \pm 4.756$ & 512.36 & $\begin{array}{c}3.555 \\
(\mathrm{~S})\end{array}$ & Day 5 & $24.90 \pm 6.691$ & 109.00 & $3.555(\mathrm{~S})$ \\
\hline Day 10 & $25.50 \pm 4.301$ & & & Day 10 & $28.40 \pm 5.854$ & & \\
\hline
\end{tabular}

Table 3: Comparison of scores of (a) NPRS between Group A and Group B (b) NDI between Group A and Group B (c) Lateral flexion of neck (Right) between Group A and Group B (d) Lateral flexion of neck (Left) between Group A and Group B

\begin{tabular}{|c|c|c|c|c|c|c|c|c|c|}
\hline \multicolumn{5}{|c|}{ (a) } & \multicolumn{5}{|c|}{ (b) } \\
\hline NPRS & $\begin{array}{c}\text { Group A } \\
\text { Mean } \pm \\
\text { SD }\end{array}$ & $\begin{array}{c}\text { Group B } \\
\text { Mean } \pm \\
\text { SD }\end{array}$ & $\begin{array}{c}P \\
\text { value }\end{array}$ & t-test & NDI & $\begin{array}{c}\text { Group A } \\
\text { Mean } \pm \\
\text { SD }\end{array}$ & $\begin{array}{c}\text { Group B } \\
\text { Mean } \pm \text { SD }\end{array}$ & $\begin{array}{c}\mathbf{P} \\
\text { value }\end{array}$ & t-test \\
\hline Day 1 & $\begin{array}{c}6.50 \pm 0.70 \\
7\end{array}$ & $\begin{array}{c}6.50 \pm 0.85 \\
0\end{array}$ & 1.000 & $\begin{array}{c}0.000 \\
(\mathrm{NS})\end{array}$ & Day 1 & $\begin{array}{c}50.60 \pm 9.27 \\
6\end{array}$ & $\begin{array}{c}50.30 \pm 12.2 \\
02 \\
\end{array}$ & $\begin{array}{c}0.951 \\
3\end{array}$ & $\begin{array}{c}0.062 \\
(\mathrm{NS})\end{array}$ \\
\hline Day 5 & $\begin{array}{c}3.50 \pm 1.35 \\
4\end{array}$ & $\begin{array}{c}4.10 \pm 0.99 \\
4\end{array}$ & $\begin{array}{c}0.273 \\
5\end{array}$ & $\begin{array}{l}1.129 \\
(\mathrm{NS})\end{array}$ & Day 5 & $\begin{array}{c}29.30 \pm 6.14 \\
7\end{array}$ & $\begin{array}{c}35.40 \pm 10.5 \\
41\end{array}$ & $\begin{array}{c}0.156 \\
9\end{array}$ & $\begin{array}{l}1.477 \\
\text { (NS) }\end{array}$ \\
\hline Day 10 & $\begin{array}{c}1.40 \pm 0.69 \\
9\end{array}$ & $\begin{array}{c}2.10 \pm 0.73 \\
8\end{array}$ & $\begin{array}{c}0.043 \\
0\end{array}$ & $\begin{array}{c}2.178 \\
(\mathrm{~S})\end{array}$ & Day 10 & $\begin{array}{c}14.10 \pm 0.69 \\
9\end{array}$ & $\begin{array}{c}19.70 \pm 8.61 \\
6\end{array}$ & $\begin{array}{c}0.102 \\
7\end{array}$ & $\begin{array}{c}1.719 \\
(\mathrm{~S})\end{array}$ \\
\hline \multicolumn{5}{|c|}{ (c) } & \multicolumn{5}{|c|}{ (d) } \\
\hline $\begin{array}{c}\text { Lateral } \\
\text { Bending } \\
\text { of Neck } \\
\text { (Right) }\end{array}$ & $\begin{array}{c}\text { Group A } \\
\text { Mean } \pm \\
\text { SD }\end{array}$ & $\begin{array}{c}\text { Group B } \\
\text { Mean } \pm \\
\text { SD }\end{array}$ & $\begin{array}{c}P \\
\text { value }\end{array}$ & t-test & $\begin{array}{c}\text { Lateral } \\
\text { Bending } \\
\text { of Neck } \\
\text { (Left) }\end{array}$ & $\begin{array}{c}\text { Group A } \\
\text { Mean } \pm \\
\text { SD }\end{array}$ & $\begin{array}{c}\text { Group B } \\
\text { Mean } \pm \text { SD }\end{array}$ & $\begin{array}{c}\mathbf{P} \\
\text { value }\end{array}$ & t-test \\
\hline Day 1 & $\begin{array}{c}20.10 \pm 4.1 \\
49 \\
\end{array}$ & $\begin{array}{c}19.20 \pm 4 . \\
29\end{array}$ & $\begin{array}{c}0.639 \\
2 \\
\end{array}$ & $\begin{array}{r}0.477 \\
(\mathrm{NS}) \\
\end{array}$ & Day 1 & $\begin{array}{c}26.10 \pm 4 . \\
748 \\
\end{array}$ & $\begin{array}{c}22.40 \pm 5.89 \\
2 \\
\end{array}$ & $\begin{array}{c}0.139 \\
4 \\
\end{array}$ & $\begin{array}{l}1.546 \\
(\mathrm{NS}) \\
\end{array}$ \\
\hline Day 5 & $\begin{array}{c}23.70 \pm 4.4 \\
23 \\
\end{array}$ & $\begin{array}{c}21.80 \pm 4 . \\
756\end{array}$ & $\begin{array}{c}0.369 \\
2 \\
\end{array}$ & $\begin{array}{c}0.925( \\
\mathrm{NS}) \\
\end{array}$ & Day 5 & $\begin{array}{c}29.00 \pm 5 . \\
142\end{array}$ & $\begin{array}{c}24.90 \pm 6.69 \\
1 \\
\end{array}$ & $\begin{array}{c}0.141 \\
8 \\
\end{array}$ & $\begin{array}{l}1.536 \\
(\mathrm{NS}) \\
\end{array}$ \\
\hline Day 10 & $\begin{array}{c}31.20 \pm 4.4 \\
92\end{array}$ & $\begin{array}{c}25.50 \pm 4 . \\
301\end{array}$ & $\begin{array}{c}0.009 \\
6\end{array}$ & $\begin{array}{c}2.898 \\
(\mathrm{NS})\end{array}$ & Day 10 & $\begin{array}{c}33.50 \pm 5 \\
359\end{array}$ & $\begin{array}{c}28.40 \pm 5.85 \\
4\end{array}$ & $\begin{array}{c}0.057 \\
2\end{array}$ & $\begin{array}{c}2.032 \\
(\mathrm{NS})\end{array}$ \\
\hline
\end{tabular}




\section{Results}

All participants completed the program without any adverse effects and found the improvement in cervical range of motion, resolve pain and neck stiffness. Comparison of scores for each component of NPRS, NDI and lateral flexion of neck both sides on the $1^{\text {st }}$, $5^{\text {th }}$ and $10^{\text {th }}$ day for both the groups was done using unpaired t-test with assuming no normality and for $\mathrm{p}$ $>0.05$.

\section{$>$ Comparison within group $\mathbf{A}$}

Table 1 (a), (b), (c) and (d) shows comparison of NPRS, NDI, lateral flexion of neck (right) and lateral flexion of neck (left) respectively and result for the variable was significant.

\section{$>$ Comparison with in group $B$}

Table 2 (a), (b), (c) and (d) shows comparison of NPRS, NDI, lateral flexion of neck (right) and lateral flexion of neck (left) respectively and result for the variable was significant.

\section{$>$ Comparison between the group A and group B}

Table 3 (a) shows the comparison of NPRS between group A and group B. On comparing Mean \pm SD of $1^{\text {st }}, 5^{\text {th }}$ and no significant difference observed, while on $10^{\text {th }}$ day significant difference found.

Table 3 (b) shows the comparison of NDI between group A and group B. On comparing Mean \pm SD of $1^{\text {st }}, 5^{\text {th }}$ day but no significant difference found, while on $10^{\text {th }}$ day significant difference found.

Table 3 (c) shows the comparison of Lateral Flexion of neck (Right) between group A and group B. On comparing Mean $\pm \mathrm{SD}$ of $1^{\text {st }}, 5^{\text {th }}$, but no significant difference found while on $10^{\text {th }}$ day, significant difference found.

Table 3 (d) shows the comparison of Lateral Flexion of neck (Left) between group A and group B. On comparing Mean $\pm \mathrm{SD}$ of $1^{\text {st }}, 5^{\text {th }}$ but no significant difference found while on $10^{\text {th }}$ day, significant difference found.

Thus the findings of present study support the $\mathrm{H}_{1}$ and $\mathrm{H}_{2}$ of hypothesis. There is significant difference in variables after both the interventions but deep transverse friction massage shows more improvement in patients with upper trapezius trigger points.

\section{Discussions}

The study focused on determining the effectiveness of both deep transverse friction massage and ultrasound when treating the patients with upper trapezius trigger points. The data analysis revealed that there were significant improvements in cervical ROM (lateral flexion both sides) statistically. Similar results were shown in a study conducted by Sharma et al 2010 when two different trigger point techniques were used in combination with the ultrasound and massage. ${ }^{19}$ Significant differences were observed in the NPRS score $(p<0.05)$ and NDI in both the groups. The group receiving ultrasound showed improvement in the pre and post score of the treatment. Hence ultrasound treatment with deep pressure works on the painful tissues and resolves pain that further increases the ROM. Researchers found that at the depth of $5 \mathrm{~cm}$, ultrasound followed by ice treatment yielded little or no thermal benefits. ${ }^{20}$ The objective was to warm muscle, tendons and other tissues to improve blood circulation or blood movement and to accelerate the healing process. ${ }^{21} \mathrm{~A}$ study on human muscle by Draper et al has shown that, treatment more than 10 minutes of $1-\mathrm{MHz}$ constant ultrasound at intensity of $1.5 \mathrm{~W} / \mathrm{cm}^{2}$ with $80 \mathrm{~cm}^{2}$, the temperature in the gastrocnemius muscle at a depth of $3 \mathrm{~cm}$ was amplified by $5^{\circ} \mathrm{C}^{22}$ The treatment was given for $5-$ $7 \mathrm{~min}$ for deep friction massage, for 10 days and ultrasound was given with an intensity of 1.5 watt $/ \mathrm{cm}^{2}$, with $40-50 \mathrm{~cm}^{2}$ for 10 days. The post score on the $10^{\text {th }}$ day showed significant improvements in pain intensity along with the lateral flexion of neck to both sides. But when they both were compared, deep friction massage showed significant improvement over ultrasound.

Initially, deep friction massage was actually claimed to be too strenuous to administer ${ }^{23}$ but later on, a Cochrane review conducted on randomized control trails and clinical controlled trails claimed deep transverse friction massage (DTFM) to be one of the essential physiotherapy interventions for the management of tendinitis and soreness. ${ }^{24}$ Mayer et al in the study showed a relief in pain up to $50 \%$ with deep friction massage among 31 male sprinters with one-sided untreated achilles tendinopathy. ${ }^{25}$ According to the World Federation for ultrasound in Medicine and Biology ${ }^{26}$ ultrasound on another days for a lapse of either 1 or 3 weeks enhanced arteriole blood movement, this dose was selected because same intensity was used by Dyson et al for the management 
of people with varicose ulcers hence revealing the clinical significance. ${ }^{27}$ Multiple studies has shown the effectiveness of massage therapy in reducing pain ${ }^{28}$ and increasing $\mathrm{ROM}^{29}$.

Researchers claim that treatment sessions are directly dependent on the phase and site of the lesion. ${ }^{30}$ It was found that massage therapy decreased pain and works effectively more in patients with uncomplicated upper trapezius spasm after 10 treatment sessions. The improvement in pain and function is due to the time spending by therapist, treatment in peaceful and relaxing environment, enhancing body functions awareness. $^{31}$ Several therapies and modalities have been tested with contradicting results and till now no single treatment strategy is accepted. ${ }^{32}$

\section{Conclusions}

This study concluded that Deep Transverse Friction Massage and Ultrasound both are effective in treatment of myofacial trigger points of upper trapezius muscle but clinically Deep Transverse Friction Massage shows better results.

\section{Limitations of the study}

$>$ The sample size for the study was too small.

$>$ Duration of the study was not adequate to study the long term effects of the treatment

$>$ External factors affecting the progression cannot be calculated.

$>$ The study was limited to 10 sessions only and there was no follow up after that.

\section{Ethical Clearance}

No ethical clearance required.

\section{Source of funding}

No funding was required to carry out this work. We are thankful to Dr Jitendra Shrama, Principle, DAV Institute of Physiotherapy and Rehabilitation, Jalandhar, Punjab-144008.

\section{Conflicts of Interest}

Authors declare that there is no conflict of interest.

\section{REFERENCES}

1) Lehman JJ, Anderson D, Taylor M. ACA NewsNovember 2014.

2) Yunus M. Fibromyalgia syndrome and myofascial pain syndrome. Myofascial Pain and
Fibromyalgia, Trigger Point Management. St. Louis: Mosby. 1994:3-1.

3) Moore KL, Dalley AF, Agur AM. Clinically oriented anatomy. Lippincott Williams and Wilkins; 2013 Feb 13.

4) Chaurasia BD. BD Chaurasia's Human Anatomy. CBS Publishers and Distributors PVt Ltd.; 2010.

5) Hong CZ. Pathophysiology of myofascial trigger point. Journal of the Formosan Medical Association= Taiwan yi zhi. 1996 Feb; 95(2):93104.

6) Mense S, Simons DG, Russell IJ. Muscle pain: understanding its nature, diagnosis, and treatment. Lippincott Williams and Wilkins; 2001.

7) Simons DG. Diagnostic criteria of myofascial pain caused by trigger points. Journal of Musculoskeletal Pain. 1999 Jan 1; 7(1-2):111-20.

8) Rachlin ES. History and physical examination for regional myofascial pain syndrome. Myofascial pain and fibromyalgia: trigger point management. St. Louis: Mosby. 1994:159-72.

9) Gajdosik RL, Bohannon RW. Clinical measurement of range of motion. Phys ther. 1987 Dec;67(12):1867-72.

10) McCarthy MJ, Grevitt MP, Silcocks P, Hobbs G. The reliability of the Vernon and Mior neck disability index, and its validity compared with the short form-36 health survey questionnaire. European Spine Journal. 2007 Dec 1; 16(12):2111-7.

11) Hong CZ, Chen YC, Pon CH, Yu J. Immediate effects of various physical medicine modalities on pain threshold of an active myofascial trigger point. Journal of musculoskeletal Pain. 1993 Jan 1; 1(2):37-53.

12) Cassar MP. Handbook of clinical massage: A complete guide for students and practitioners. Churchill Livingstone. 2004.

13) Vickers A, Zollman C. ABC of complementary medicine: Massage therapies. British Medical Journal. 1999 Nov 6; 319(7219):1254.

14) Brooks CP, Woodruff LD, Wright LL, Donatelli $\mathrm{R}$. The immediate effects of manual massage on power-grip performance after maximal exercise in healthy adults. Journal of Alternative and Complementary Medicine: Research on Paradigm, Practice, and Policy. 2005 Dec 1; 11(6):1093-101.

15) Leivadi S, Hernandez-Reif M, Field T, O'Rourke M, D'Arienzo S, Lewis D, Pino ND, Schanberg S, Kuhn C. Massage therapy and relaxation effects on university dance students. Journal of Dance Medicine and Science. 1999 Sep 15; 3(3):108-12. 
16) Micklewright D, Griffin M, Gladwell V, Beneke R. Mood state response to massage and subsequent exercise performance. The Sport Psychologist. 2005 Sep; 19(3):234-50.

17) Hemmings B, Smith M, Graydon J, Dyson R. Effects of massage on physiological restoration, perceived recovery, and repeated sports performance. British journal of sports medicine. 2000 Apr 1; 34(2):109-14.

18) Fernández-de-las-Peñas $\mathrm{C}$, Alonso-Blanco $\mathrm{C}$, Fernández-Carnero J, Miangolarra-Page JC. The immediate effect of ischemic compression technique and transverse friction massage on tenderness of active and latent myofascial trigger points: a pilot study. Journal of Bodywork and Movement therapies. 2006 Jan 31; 10(1):3-9.

19) Sharma A, Angusamy R, Kalra S, Singh S. Efficacy of post-isometric relaxation versus integrated neuromuscular ischaemic technique in the treatment of upper trapezius trigger points. Indian Journal of Physiotherapy and Occupational Therapy. 2010 Jul;4(3):1-5

20) Draper DO, Schulthies S, Sorvisto P, Hautala AM. Temperature changes in deep muscles of humans during ice and ultrasound therapies: an in vivo study. Journal of Orthopaedic and Sports Physical Therapy. 1995 Mar; 21(3):153-7.

21) Robertson VJ, Baker KG. A review of therapeutic ultrasound: effectiveness studies. Physical Therapy. 2001 Jul 1; 81(7):1339.

22) Draper DO, Sunderland S, Kirkendall DT, Ricard M. A comparison of temperature rise in human calf muscles following applications of underwater and topical gel ultrasound. Journal of Orthopaedic and Sports Physical Therapy. 1993 May; $17(5): 247-51$.

23) Steward B, Woodman R, Hurlburt D. Fabricating a splint for deep friction massage. Journal of Orthopaedic and Sports Physical Therapy. 1995 Mar; 21(3):172-5.

24) Brosseau L, Casimiro L, Milne S, Welch V, Shea B, Tugwell P, Wells GA. Deep transverse friction massage for treating tendinitis. The Cochrane Library. 2002.

25) Mayer F, Hirschmüller A, Müller S, Schuberth M, Baur H. Effects of short-term treatment strategies over 4 weeks in Achilles tendinopathy. British journal of sports medicine. 2007 Jul 1; 41(7):e6-.

26) Barnett SB, Ter Haar GR, Ziskin MC, Rott HD, Duck FA, Maeda K. International recommendations and guidelines for the safe use of diagnostic ultrasound in medicine. Ultrasound in medicine and biology. 2000 Mar 31; 26(3):35566.

27) Dyson M, Franks C, Suckling J. Stimulation of healing of varicose ulcers by ultrasound. Ultrasonics. 1976 Sep 1;14(5):232-6.

28) van den Dolder P, Ferreira P, Refshauge K. Is soft tissue massage an effective treatment for mechanical shoulder pain? A study protocol. Journal of Manual and Manipulative Therapy. 2010 Mar 1;18(1):50-4.

29) Thompson WR, Carter R, Rohe B, Duncan RL, Cooper CR. A novel massage therapy technique for management of chronic cervical pain: a case series. International journal of therapeutic massage and bodywork. 2011;4(3):1.

30) Preyde M. Effectiveness of massage therapy for subacute low-back pain: a randomized controlled trial. Canadian Medical Association Journal. 2000 Jun 27;162(13):1815-20.

31) Avery RM. Massage therapy for cervical degenerative disc disease: alleviating a pain in the neck?. International Journal of Therapeutic Massage and Bodywork: Research, Education, and Practice. 2012 Aug 15;5(3):41-6.

32) Mukkannavar PB. Effect of combination therapy [TENS and ultrasound] and ischemic compression in the treatment of active myofascial trigger points. Journal of Exercise Science and physiotherapy. 2008 Dec;4(2):95. 